\title{
Vascular Neoplasm
}

National Cancer Institute

\section{Source}

National Cancer Institute. Vascular Neoplasm. NCI Thesaurus. Code C7388.

A benign, intermediate, or malignant neoplasm arising from vascular tissue including arteries, veins, venous sinuses, lymphatic vessels, arterioles and capillaries. It may occur in essentially any body location and is characterized by the presence of vascular channel formation and endothelial cells. 